\title{
Nutraceutical Values of Minor Fruits on Immunity Development to Combat Diseases
}

\author{
A. D. Ashok ${ }^{*}$, J. Ravivarman and K. Kayalvizhi \\ Institute of Agriculture, Tamil Nadu Agricultural University, \\ Kumulur - 621712, Trichy, India \\ *Corresponding author
}

\section{Keywords}

Minor fruits,

Underutilized fruits,

Nutraceuticals,

Anti-oxidants, Fruit

alkaloids, Medicinal fruits

Article Info

Accepted:

18 May 2020

Available Online:

10 June 2020

\section{A B S T R A C T}

Fruits play predominant role in the diet. Through the utilization of underutilized minor fruits, we can bridge this gap as they grow in adverse conditions on all kinds of soil. This strength of minor fruits is particularly useful in a country like India, where majority of the farmers are resource-poor and carry out farming under not so favourable conditions. Minor fruits are consumable to the human beings but relatively less Palatable than other fruits, which have lesser demand in the market, which are grown to a limited extent only. Amla, Bael, Jamun, Pomegranate, Jack fruit, Carambola, Phalsa, Karonda, Passion fruit, Rambutan, Wood apple, Durian, Malayan apple, Karonda, Fig, Annona, Buchanania/charoli, Garcinia gummi-gutta, Syzygium, Opuntia are some of the minor edible fruits cultivated or grown in Indian subcontinent. The minor fruits are reservoirs of several essential nutrient elements, vitamins and minerals and bioactive compounds are directly attributed to antioxidant properties against various free radicals. It is believed that regular consumption of these fruits will aid in preventing several diseases and disorders including obesity, diabetes and chronic diseases. They have a greater potential to cure several deficiency disorders and also increase the immunity against diseases. So that more awareness is created among the consumers, which will subsequently benefit to fight several nutrition related problems. Therefore, it is probably apt to call them as 'medicinal fruits' instead of nearly neglected 'minor fruits'. This review deals with the minor fruits and their nutraceutical values which improves human immune system.

\section{Introduction}

Malnutrition affects one in every three persons on the planet. A total of 159 million children under the age of five are estimated to be stunted. Two billion people are deficient in one or more micronutrients and nearly the same number are overweight or obese. Diversity in food plates balances the diets by supplying missing nutrients (Biodiversity International - India. Fact sheet 7). Fruits play predominant role in the diet. Several health based statistical reports highlight the importance of consumption of fruits as they tend to contain broad-spectrum essential nutrients including phenolic antioxidants that impart protective role against several diseases (Yallesh Kumar et al., 2018).

Through the utilization of underutilized minor fruits, we can bridge this gap as they grow in adverse conditions on all kinds of soil. 
This strength of minor fruits is particularly useful in a country like India, where majority of the farmers are resource-poor and carry out farming under not so favourable conditions (Biodiversity International - India. Fact sheet 7). Minor fruits are consumable to the human beings but relatively less Palatable than other fruits, which have lesser demand in the market, which are grown to a limited extent only. Other terms that are used for these fruits are less - known fruits, less appealing fruits, less-exploited fruits, stray fruits, wild fruits etc (Yallesh Kumar et al., 2018).

Amla, Bael, Jamun, Pomegranate, Jack fruit, Bread fruit, Carambola, Phalsa, Karonda, Passion fruit, Mangosteen, Rambutan, Wood apple, Durian, Malayan apple, Roseapple, Egg fruit, West Indian Cherry, Elephant foot apple, Mulberry, Karonda, Kokum, Fig, Ramphal, Tamarind, Lime, lemon, Mandarin and Annona, Aporosa, Artocarpus/wildJack, Berberis, Buchanania/charoli, Elaeagnus, Garcinia gummi-gutta, Syzygium, Opuntia, Lantana, Ixora, Hulagada hannu, Haale hannu, Chotte hannu etc. (Abhishek et al., 2017) are some of the minor edible fruits cultivated or grown in Indian subcontinent.

\section{Nutraceutical value of minor fruits}

Scientific reports state that fruits play an important role in treating several diseases. They are useful in curing nutrient deficiency diseases. There are several examples available in Ayurvedic literature about the role of different fruits in human diet. They are the food products supplemented with herbal ingredients, vitamins, minerals and nutrients (Yallesh Kumar et al., 2018). They are now popularly known as 'Nutraceuticals', the word first coined in 1996 by Stephen De Felice. These are defined as parts of a food or a whole food that have a medicinal or health benefit including prevention and treatment of disease. These are bridge the gap between food and medicines. Besides basic nutritional value, they provide health and medicinal benefits Excessive free radical concentration in the body cause damage to DNA, proteins \& natural defense enzymes and may cause health problems. Nutraceuticals exhibit antioxidant activity and act as scavengers of free radicals $(\mathrm{OH}, \mathrm{OOH}, \mathrm{OOR}$, Singlet oxygen) that damage our body. (DeFelice, 1996)

These fruits have both restorative as well as curative properties viz. aromatic, cooling, digestive, stomachic, stimulant, astringent, emollient, useful in seasoning, maturation and fermentation of culinary, processed food and drinks. There are few other fruits which possess specific properties such as diuretic, diaphoretic, sedative or stimulant to nerves, improver of peristaltic movements of intestine and liver ailment, cardio tonic, relieving cough, cold, bronchitis, asthmatic spasm, blood pressure etc. Some minor fruits contain essential oils in their peel, foliage or roots and exhibit carminative and germicidal properties. In addition to their therapeutical values, these fruits provide nutrition, strength and vigour to our body and restore loss of minerals and amino acids, thus protecting it against many deficiencies and diseases. Some of the other minor fruits found in the regions are fairly good source of ascorbic acid viz. Artocarpus spp. Bael, Wood apple and Amla were found to be rich source of calcium (Singh et al., 2003; Mazumdar, 2004, Abhishek et al., 2017). The medicinal value is subordinated to the nutraceutical value and certain minor fruits might have medicinal qualities, one of the possible functions of nutrients being also the therapeutic one. There is also an important ethno-botanical tradition of the folk medicine from all the countries that have kept from old times the knowledge about the healing features of fruits, picked up from nature or cultivated (Edonia, 2001, Anupam, 2013 Ghosh, 2017). According to Vietmeyer 
(1990), in India, about 2000 species have edible fruits and are found in Western Ghats of Maharashtra, Karnataka, Kerala, Goa and also some parts of North Eastern states found in evergreen and semi-evergreen forests (Krishnamurthy, 2011).

\section{Minor fruits grown in India}

Minor fruits grown in India, wildly or cultivated locally and for home garden but currently having low export and local market value are recorded in the following.

\section{Aonla or amla (Emblica officinalis)}

It is also called as 'Goose berry, The Ayurvedic wonder'. The fruit of amla have enormous medicinal values. Fruits are highly nutritious as it contains carbohydrates, fiber and minerals like calcium, prosperous, iron, vitamin $\mathrm{C}$ and vitamin B complex (Yallesh Kumar et al., 2018). Medicinal properties: Antiscorbutic (cures scurvy), diuretic, laxative, antibiotic and anti-dysenteric. The fruits contain proteins, ascorbic acid and higher concentrations of most minerals and amino acids. Glutamic acid, proline, aspartic acid, alanine and lysine are the important amino acids present in amla fruits. It is profusely used in the process of complete rejuvenation of the body. It prevents grey hair, hair falling, is anti-aging, and purifies blood. It is very useful in constipation. It has recorded evidences of increasing eyesight and aphrodisiac effects. It also helps in digestion of food. It is astringent in taste and cause cooling effect on the body. The fruit is acrid, cooling refrigerant, diuretic and laxative. The dried fruit is useful in hemorrhage, diarrhea and dysentery. They are anabolic, antibacterial and resistance building. They possess expectorant, cardio tonic, anti-pyretic, anti-oxidative, antiviral and anti-emetic activities. They are also used in the treatment of leucorrhoea and artheroschlerosis. It is highly useful in treating respiratory problems like, asthma, bronchitis, tuberculosis, etc. It is very useful in diabetes, skin diseases, diarrhea, piles, pain, white discharges, bleeding disorders, kidney problem and cataract. It is the main ingredient of the ayurvedic preparation 'Chyavanprasha' and one of the three ingredients of 'Thiphala choorna', (mixture of Amla, Terminalia chebula and T. bellerica) Brahma Rasayana and Madumegha churna which is a health and digestion tonic, which also prevents hair from premature graying and falling. Even amla flowers have laxative properties. Amla juice along with bitter gourd juice taken daily stimulates the pancreas to produce more insulin. Similarly, a mixture of amla powder, jamun seed powder and bitter gourd powder taken daily for best results. Dried amla mixed with jaggery is a very effective cure for rheumatism. Phylloemblin, obtained from fruit pulp has been found to have mild depressant action on central nervous system and good liver tonic (Farooqi, 2015). Water in which dried amla is soaked makes a soothing lotion for eyes, while amla juice with honey is useful in preserving eye sight, curring glaucoma and conjunctivitis. Regular dose of the juice improves eyesight and good for eye muscles. (L.N Hegade, 2005). Recent study reported that aonla extracts have anti-fungal, anti-bacterial (Sidhu et al., 2007) and antiviral properties (Balasubramaniam et al., 2007).

Avocado/Butter fruit (Persea Americana) are consumed primarily as fresh. They are neither sweet nor acidic. It is reputed as a nourishing food of high dietic value. Its nutritional values are comparable to ripe olives. Since the fruits contain less than one per cent sugar, it is recommended as high-energy food for diabetics. Its energy value is twice as much as banana fruit. The avocado oil is used in preparation of cosmetics (Mazumdar, 2004). Bael (Aegle marmelos) is considered as a sacred tree by the Hindus. 
The bael fruits are the major source of medicinal properties and it can branded as Nature's Most Natural Medicinal Fruit (Yallesh Kumar et al., 2018). The mature fruits are astringent, digestive and stomachic are usually prescribed for diarrhea and dysentery. The ripe fruits are tonic, restorative, laxative and good for heart and brain. Methanolic extract of leaves showed very good anti - bacterial property.

The medicinal value of Bael fruit is enhanced due to presence of Tanin, the evaporating substance in its rind. The rind contains $20 \%$ and the pulp has only $9 \%$ of Tanin. This substance helps to cure diabetes. Ripe fruit is taken during summer to keep the body and mind cool. Bael also helps to sharpen intellect and concentration of mind (Yallesh Kumar et al., 2018).

Ber (Ziziphus mauritiana) is supposed to be native to India, Indo-Malayan region including Myanmar. It is commonly found in drier regions. Its fruits are mostly eaten fresh, but can be also be processed into delicious murabba, candies and dehydrated products. Fruits are also used to prepare jam and wine (Biodiversity International - India. Fact sheet 7). Carambola (Averhoa carambola) is credited with medicinal properties. Carambola contains a relatively high oxalic acid and sour in taste which makes it little commercial value for consumption as a fresh fruit. However, new sweet- flavored cultivars with a low oxalic acid concentration are rapidly becoming popular.

Fruits are important sources of minerals like potassium, iron, calcium, sodium and phosphorus. The ripe fruit is digestible, tonic and strengthening. The juice of fruit, when used as eye drop, is also considered to be useful for vision. These fruit also allay thirst. The ripe fruit said to be a good remedy for bleedings piles, particularly the internal one.
The dried fruit is given in some parts of India in fevers (Hazarika and Lalruatsangi, 2016). Chironji (Buchanania lanzan) is an another native fruit to Indian subcontinent. Nutritional composition of the seeds shows that it as a potential source of protein, fat, dietary fiber, and energy. It is very good source of Phosphorus, Calcium, Magnesium and Iron. It contains $3.0 \mathrm{~g}$ moisture, $19.0 \mathrm{~g}$ protein, $59.1 \mathrm{~g}$ fat, $3.8 \mathrm{~g}$ fibre, $12.1 \mathrm{~g}$ carbohydrates, $279 \mathrm{mg}$ calcium, $528.0 \mathrm{mg}$ phosphorus, $8.5 \mathrm{mg}$ iron, $0.69 \mathrm{mg}$ thiamine, $0.53 \mathrm{mg}$ riboflavin, $1.5 \mathrm{mg}$ niacin and $5.0 \mathrm{mg}$ vitamin $\mathrm{C}$ per $100 \mathrm{~g}$ of kernel and provides 656 calories (Anon, 1990). The fruit has high socioeconomic value providing livelihood to tribal population of the region and has high potential as commercial fruit species. The fruit is juicy and sweet in taste and used for preparation of various value added products like squash, ready to serve (R.T.S.) drinks and nectar after juice extraction. Chironji kernel contains about $52 \%$ oil (Amit Kumar Singh et al., 2019). Kernel oil is used mostly in cosmetic manufacturing and substitute for olive and almond oils (Siddiqui, 2014).

The polyphenols have been proven for its disease fighting power and possess good antioxidant activities. The fatty acids, polyphenols, phytosterols and stigmasterol in seed extract has both medicinal and nutritional value (Amit Kumar Singh et al., 2019). Custard Apple/Sweet Sop (Annona squamosa) is an important table fruit. Apart from fresh consumption, the pulp of $A$. squamosa can be processed to prepare products like pastries, chocolates, ice cream and mixed fruit jam. Extracts of A. muricata (sour sop) are currently being studied as a potential treatment for various types of cancer. Seeds of most of these species contain insecticidal properties and are locally used to control pests. Green leaves yield essential oil (Biodiversity International - India. Fact sheet 7). 
Delinia (Dillenia indica) or Elephant apple is a large, knobby fruit with acidic flavoured. Fruits are consumed as tonic and laxative. The fruit juice is mixed with sugar and used as a cooling beverage in fevers and as a cough mixture. Green fruits are very effective against rheumatism (Hazarika and Lalruatsangi, 2016). Durian (Durio zibethinus) is one of the popular seasonal fruit in South East Asia. It is popular because of its taste and strong odour. The fruit is usually consumed fresh, but it can be processed into paste, or the flesh can be frozen or powdered or added into other products such as ice cream, cakes and confectionery, seeds roasted and eaten (Hazarika and Lalruatsangi, 2016). Fig (Ficus carica) are laxative and are rich in protein digestive enzymes. It is also effective in the treatment of piles, constipation, asthma, corns, and chronic cough. It is an excellent tonic for weak people who suffer cracks in lips, tough and mouth. It is rich in calories (269 IU), protein, calcium (higher than milk), iron and highest fiber content. Fig has nutritive index 11 as against 9, 8, 6 of apple, raisin and dates, respectively.

Total sugar content of fresh fig is 16 per cent and of dried is 52 per cent. It is valued for its laxative properties and is used in the treatment of skin infections. Fruits help to maintain acid- alkali balance of the body (Mazumdar, 2004). Garcinia gummi-gutta is widely distributed along the lower altitude of Western Ghats (coastal region). Fruit juice exhibits anti-scorbutic, anthelmintic and cardiotonic properties. Moreover, fruit rind and seeds are potential source of bioactive compounds such as lipids, fatty acids and nutraceuticals. The fruit is commercially exploited for its weight loss properties (Naveen and Krishnakumar, 2013; Mahesh et al., 2016). Garcinia indica, a tree commonly found along the coastal area of the Western Ghats. Garcinia comprises several potential bioactive constituents, majority proportions of them being garcinol and hydroxycitric acid (HCA). The pulp of the fruit is acidic that tastes sour. Generally, the rind of the fruit is commercially exploited as it is considered to be potentially therapeutic; it is used as souring agent in most of south Indian coastal cuisines. Moreover, the butter extracted from rind finds application in nutraceutical and cosmetic industries. Furthermore, is used to prepare several kinds of beverages and functional foods (Baliga et al., 2011).

Jackfruit (Artocarpus heterophyllus) is one of the largest fruits in nature; considered as 'the jack of all fruits'. It is a very familiar fruit among Indians. The consumption of the fruit will cure a variety of nutritional deficiency disorders. This often underrated fruit which when ripe, is considered to have, along with the avocado and the olive, the healthiest mix of nutrients for human dietary needs, having almost the exact nutritional equivalents of mother's milk. Fruit is rich in vitamins, A, B and $\mathrm{C}$, potassium, calcium, iron, proteins. The high levels of carbohydrates in it makes the jackfruit a cheap, easily available supplement for other staple foods like rice. As the fruit flakes are difficult to digest, the people with poor digestibility have to avoid this fruit. Owing to its numerous culinary uses and its availability in plenty during the heavy monsoon rains, it has earned the welldeserved name 'Poor man's food'. Medicinal Uses: The Chinese consider jackfruit pulp and seeds tonic, cooling and nutritious, and to be "useful in overcoming the influence of alcohol on the system." The seed starch is given to relieve biliousness and the roasted seeds are regarded as aphrodisiac. The ash of jackfruit leaves, burned with corn and coconut shells, is used alone or mixed with coconut oil to heal ulcers. Mixed with vinegar, the latex promotes healing of abscesses, snakebite and glandular swellings. The root is a remedy for skin diseases and asthma. An extract of the root is taken in cases of fever and diarrhea 
(Sarala and Krishnamurthy, 2014). Jamun (Syzygium cumini) are good source of iron. Jamun fruits are used as an effective medicine against diabetes, heart and liver trouble. The powder of seeds has high value being useful in the treatment of diabetes. The delay in glucose absorption caused by fiber content is beneficial for individual with diabetics, because glucose is released more slowly in to the blood stream. Therefore, the jamun fruits are having high value in terms of therapeutic and nutrition. Antioxidant activity of Jamun is due to anthocyanins, gallic acid, quercetin etc. Juice is diuretic and prevents enlargement of spleen.

The fruit extract prevents oxidation of LDL, control; prevent atherosclerosis, cancer, and cardiovascular/ inflammatory diseases. Consumption of fresh fruits purifies blood, avoids bad breath, Strengthens gum and teeth. Gargling of fruit juice cures throat pain. The fruits are good for phlegm, constipation and piles. The fruit juice sherbet is very effective against diarrhoea and dysentery. It is good for liver; in turn it controls the blood sugar in the body. Consumption of fruits improves digestion and prevents tiredness (Hegade, 2005, Gayathri et al., 2012, Shilpa and Krishnakumar, 2015). Karanda (Carissa carandas) fruits are richest source of iron, containing good amount of vitamin C. They are very useful to cure anemia. The fruits are traditionally used for medicinal treatments, of malaria, epilepsy, nerve disorder, relieve of pain and headache, fever, blood purifier, itches and leprosy (Amit Kumar Singh et al., 2019). The major bioactive, constituents, which impart medicinal value to the herb, are alkaloids, flavonoids, saponins and large amounts of cardiac glycosides, triterpenoids, phenolic compounds and tannins. Fruits have been reported to contain carisol, $\beta$ caryophyllene, carissone, carissic acid, carindone, carinol, ascorbic acid, lupeol, and $\beta$-sitosterol.
These chemicals are very effective in the treatment of scabies, intestinal worms, pruritus, biliousness and also used as antiscorbutic, anthelmintic (Amit Kumar Singh et al., 2019). Longan (Dimocarpus longan Lour.) is a subtropical fruit can be eaten fresh, dried or quick frozen. The fruit can be peeled, pitted and canned. The juice of most cultivars is sufficiently sweet for processing without addition of sugar. The flesh of the fruit is administered as a stomachic, febrifuge and vermifuge, and is regarded as an antidote for poison. A decoction of the dried flesh is taken as a tonic and treatment for insomnia and neurasthenic neurosis. Dried flowers are used for medicinal purposes. The seeds are administered to counter act heavy sweating and the pulverized kernel, which contains saponin, tannin and fat, serves as astyptic (Hazarika and Lalruatsangi, 2016). Opuntia dillenii (Ker Gawl.) Haw is native to Central America and widely distributed in the Western Ghats. Pulp is utilized to make into syrup, jam or jelly, a rich source of betalins (Pooja and Vidyasagar, 2016).

Passion fruit (Passiflora incarnate) pulp is rich in vitamin $\mathrm{A}$ and $\mathrm{C}$ and beta - carotene. It has fair amounts of $\mathrm{Na}, \mathrm{Mg} \mathrm{S}$ and chlorides. The fruit is recommended as a medicine for anxiety and insomnia. It has been used as a mild sedative since ancient times. It was used as a cure for nervous restlessness and gastrointestinal spasm. Now, it is widely approved that passion fruit juice could reduce anxiety due to mental tension, bring relaxation and induce sleep. Flavonoids are responsible for these effects (Yallesh Kumar et al., 2018). Persimmon (Diospyros kaki) fruit is used as an astringent for treating sores in the throat and mouth. They also used that quality of the fruit to treat hemorrhoids, and they chewed the bark to treat heartburn. Truly, persimmon fruit has lot of medicinal properties. The calyx of the persimmon fruit where it is 
connected to the branch of the tree can be used to make a calyx tea. Drinking calyx tea is good for stopping hiccup, and is also good for bed-wetting. For bee sting, paste a grinded astringent persimmon is very effective (Hazarika and Lalruatsangi, 2016). Phalsa (Grewia subininaequalis) fruits are sub-acidic in taste and a rich source of vitamins $\mathrm{A}$ and $\mathrm{C}$. They are also rich in phosphorous, and iron. Its medicinal qualities are known since Vedic times. Its fruits are somewhat astringent and have cooling effect. They help to cure inflammation, heart and blood disorders, fever and constipation (Mazumdar, 2004). Pomegranate (Punica granatum) is a juicy fruit, which is available in every region of the country. This nutritious fruit is of three types, the sour, sweet and sweet- sour type. The sour type is grown widely in our country. This has the acidic effect and helps to bring down phlegm. Those who have acidity should take this in small quantity. The sweet type has several medicinal properties. It is mild laxative. The fruit helps to sharpen one's memory power. It has a toning effect on the skin and is used in the preparation of skin tonics. It aids in digestion and is good for heart patients. Its iron and pectin contents are considerable. It enriches haemoglobin content in the blood. People suffering from piles will benefit from Pomegranates. The sweet juice makes the bones grow firm in children. In northeastern regions, the juice is even used to knead flour. This provides strength without inducing fat in the body. It is rich in phosphorous, calcium, and iron. The rind of the fruit is useful for children. For loose motion, two spoons of rind paste in juice extract with jaggery will control the dysentery. Fruit juice is tonic for intestine and the liver. For eye irritation and common eye pain, Pomegranate leaf paste will provide relief when applied on eyelids. Hair oil prepared from fruit juice $(1 \mathrm{~kg})$, leaf paste $(100 \mathrm{~g})$ in mustard oil massaging the hair gives healthy growth of hair.
Rind powder is the main constituent of ayurvedic preparations 'Dadimastaka choorna' and 'Bhaskara lavana choorna' (Yallesh Kumar et al., 2018). Prunus nepaulensis is locally known as Sohiong and it belongs to family Rosaceae This crop is an important indigenous underutilized fruit of Khasi and Jaintia Hills in Meghalaya. Sohiong fruits have good quantity of TSS, $\beta$ carotene, anthocyanin, fibre and potassium contents. (Rymbai et al., 2016). Rambutan (Nephelium lappaceum) or hairy litchi is a delicious fruit common in Arunachal Pradesh. The white semi-translucent, sub-acid sweet flavored aril is the edible flesh of the fruit. Fruit used for dysentery and as warm carminative in dyspepsis. Fruit decoction used for diarrhea (Hazarika and Lalruatsangi, 2016). Wood Apple (Feronia limonia) also known as monkey fruit, curd fruit. The ripe fruits contain sweet aromatic pulp, which has $74 \%$ moisture, $7.3 \mathrm{~g}$ protein, $15.5 \mathrm{~g}$ carbohydrates, $170 \mathrm{mg}$ riboflavin, $2 \mathrm{mg}$ vitamin $\mathrm{C}$ per $100 \mathrm{~g}$ of pulp and minerals, especially $0.17 \%$ calcium $0.08 \%$ phosphorus and $0.07 \%$ Iron (Morton, 1987). The fruits contain phytochemicals (polyphenols, phytosterols, saponins, tannins, coumarins, triterpenoids), vitamins, amino acids etc. [38]. It has curative value for various diseases of bones and joints, bilious diseases, prevention of capillary bleeding, cold, influenza, piles, dysentery, habitual constipation and scurvy. The fruit used as a liver and cardiac tonic, diarrhoea and dysentery (Diengngan and Hasan, 2015).

These minor fruit crops are present around us in unsystematic manner. So, cultivation of these crops in systematic manner and efficient utilization of marketing systems and channels for fresh fruits and processed products can motivate the growers towards growing these crops and can uplift the economy of country. The fruits are reservoirs of several essential nutrient elements, vitamins and minerals. 
Bioactive compounds in fruits are directly attributed to antioxidant properties against various free radicals. Regular consumption of these fruits will aid in preventing several diseases and disorders including obesity, diabetes and chronic diseases. They have a greater potential to cure several deficiency disorders and also increase the immunity against diseases. So that more awareness is created among the peoples to utilize these kind of fruits, which will subsequently benefit to fight several nutrition related problems. There is tremendous scope of utilizing these crops in different promising value added products to the food and nutraceutical industry. The value added product can meet the dearth of new product in the market and serve the purpose of nutritional security along with healthy and safe life.

\section{References}

Abhishek M., D. Thangadurai, J. Sangeetha, B. Shivanand and Ravi H. 2017. Unexploited and underutilized wild edible fruits of western Ghats in southern India. Scientific Papers. Series A. Agronomy. 2:326-339.

Amit Kumar Singh, Ranjit Pal, Ghanshyam Abrol, Shailja Punetha, Priyanka Sharma and AK Pandey. 2019. Nutritional and Medicinal Value of Underutilized Fruits. Acta Scientific Agriculture. 3(1): 16-22.

Anon. 1990. Plants for reclamation of wastelands. Publication and Information Directorate, CSIR, New Delhi. 684

Anupam P. 2013. Minor and uncultivated fruits of Eastern India. Proceedingsm of the 2nd International Symposium on Minor Fruits and Medicinal Plants for better lives. 54-67.

Balasubramanian G., Sarathi Mani, Rajesh kumar Subaschandrabose and Hameed, A S. 2007. Screening the antiviral activity of Indian medicinal plants against White spot syndrome virus in shrimp. Aquaculture. 263. 15-19. 10.1016/j.aquaculture.2006.09.037.

Baliga M.S., H.P. Bhat, R.J. Pai, R. Boloor and Palatty P.L. 2011. The chemistry and medicinal uses of the underutilized Indian fruit tree Garcinia indica Choisy (Kokum): a review. Food Res Int. 44:1790-1799.

Defelice S.L. 1996. The nutraceutical initiative: a recommendation for U.S. Economic and regulatory reforms. Genetic Engineering News. 12:13-15.

Diengngan S. and Hasan M.A. 2015. Genetic Diversity of Underutilized Fruits in India for Environmental Sustainability. Advances in Plants and Agriculture Research. 2(7): 1-6.

Edonia Group Inc. Nutraceuticals. Study No. 1414, USA, 2001.

Farooqi A.A. and Sreeramu B.S. 2005-2015. Cultivation of Medicinal and Aromatic crops Farooqi, S, In: 555 medicinal plants field and laboratory manual International book distributers Dehura Duan. 42-45.

Gayathri A., P.M. Benish Rose, J. Saranya, P. Eganathan, P. Sujanapal and K.P. Ajay. 2012. Antimicrobial, antioxidant, anticancer activities of Syzygium caryophyllatum (L.) Alston. International Journal of Green Pharmacy. 6: 285-288.

Ghosh. 2017. International Journal of Minor Fruits, Medicinal and Aromatic Plants. 3(1):09-15.

Hazarika B. N. and Lalruatsangi E. 2016. Minor fruits of Arunachal Pradesh and their role in ethno-medicines. International Journal of Minor Fruits, Medicinal and Aromatic Plants. 2(1): 57 $-59$.

Hegade L.N. 2005. Less known wild edible fruits and seeds of Uttar Kannada district of Karnataka. The Indian Forester. 136:1218-1222. 
Krishnamurthy S.R. and Sarala P. 2011. Determination of nutritive value of Ziziphus rugosa Lamk.: a famine edible fruit and medicinal plant of Western Ghats. Indian J Nat Prod Resources. 3:20-27.

Mahesh M.P., M. Muhammed Ali and AnuAppaiah K.A. 2016. Lipids and fatty acid profiling of major Indian Garcinia fruits: a comparative study and its nutritional impact. Am Oil Chem Soc. 93:823-836.

Mazumdar B.C. 2004. Minor Fruit Crops in India, Daya Publishing House, New Delhi.

Morton J.F. 1987. Fruits of Warm Climates. Creative Resource Systems, Inc. Winterville, N.C., USA: 503.

Naveen G.P.A.N. and Krishnakumar G. 2013. Traditional and medicinal uses of Garcinia gummi-gutta fruit - a review. Species. 4:4-5.

Pooja S. and Vidyasagar G.M. 2016. Phytochemical screening for secondary metabolites of Opuntia dillenii Haw. Journal of Medicinal Plants Studies. 4:39-43.

Rymbai H., R.K. Patel, N.A. Deshmukh, A.K. Jha and Verma V.K. 2016. Physical and biochemical content of indigenous underutilized Sohiong (Prunus nepaulensis Ser.) fruit in Meghalaya, India. International Journal of Minor Fruits, Medicinal and Aromatic Plants. 2(1); $54-56$.
Sarala P. and Krishnamurthy S. 2014. Monkey jack: underutilized edible medicinal plant, nutritional attributes and traditional foods of Western Ghats, Karnataka, India. Indian Journal of Traditional Knowledge. 13:508-518.

Shilpa K.J. and Krishnakumar G. 2015. Nutritional, fermentation and pharmacological studies of Syzygium caryophyllatum (L.) Alston and Syzygium zeylanicum (L.) DC fruits. Cogent Food Agri. 1:1018694.

Siddiqui M.Z. 2014. Buchanania lanzan: a species of enormous potentials. World Journal of Pharmaceutical Science 2(4): 374-379.

Sidhu K., J. Kaur, G. Kaur and Pannu K. 2007. Prevention and cure of digestive disorders through the use of medicinal plants. Journal of Human Ecology. 21:113 - 116.

Singh D.R., R.P. Medhi, S. Senani and Rai R.B. 2003. Nutritional aspects of Underutilized fruits of Andaman and Nicobar islands-Issue. Published by Director, CARI, Port Blair. 1-30.

Yallesh Kumar H.S., Kulapati Hippargi, S.K. Nataraj, B.S. Shivakumar, Sonthosh Hullur, M. Ganapathi and Arun Kumar Kamble. 2018. Nutraceutical and medicinal values of minor fruits in Western Ghats of South India. Journal of Pharmacognosy and Phytochemistry. SP3: 404-408.

\section{How to cite this article:}

Ashok. A. D., J. Ravivarman and Kayalvizhi. K. 2020. Nutraceutical Values of Minor Fruits on Immunity Development to Combat Diseases. Int.J.Curr.Microbiol.App.Sci. 9(06): 1303-1311. doi: https://doi.org/10.20546/ijcmas.2020.906.162 